\title{
Slope stability challenges and solutions for mining Kimberlite resources hosted in structurally complex country rock: Dip slope mining at Jwaneng Mine, Botswana
}

\author{
Oakantse Mogorosi ${ }^{1}$, Kabo Gabanakgosi ${ }^{1}$, Otsile M. Barei $^{1}$ and Thokweng Thokweng $^{1}$. \\ ['Debswana Diamond Company]
}

\section{Introduction}

The Jwaneng Diamond Mine diatremes have intruded the late Archean to early Proterozoic mixed siliciclastic - carbonate sediments of the Transvaal Supergroup. The structural geology of the country rock at Jwaneng Mine indicates that the area has been subjected to at least three deformational events. The first deformation (D1) is NW-SE directed compression which resulted in NE trending open folds (F1) and low angle thrust faults that tend to dissipate into bedding. The second deformation (D2) is N$\mathrm{S}$ shortening that resulted in sinistral, oblique shearing along the pre-existing radial cleavage developed around the F1 folds coupled with development of antithetic structures and NW-trending folds, (F2). The third deformational event, D3 is an NE-SW extensional deformation leading to development of normal faulting along pre-existing F1 cleavage creating a series of wedge shaped fault-bounded blocks. The normal faulting was coupled with rotation of blocks towards the $\mathrm{N}$ resulting high dip value on the eastern slopes daylighting in to Jwaneng mine open pit. (Creus, et al., 2017) in prep

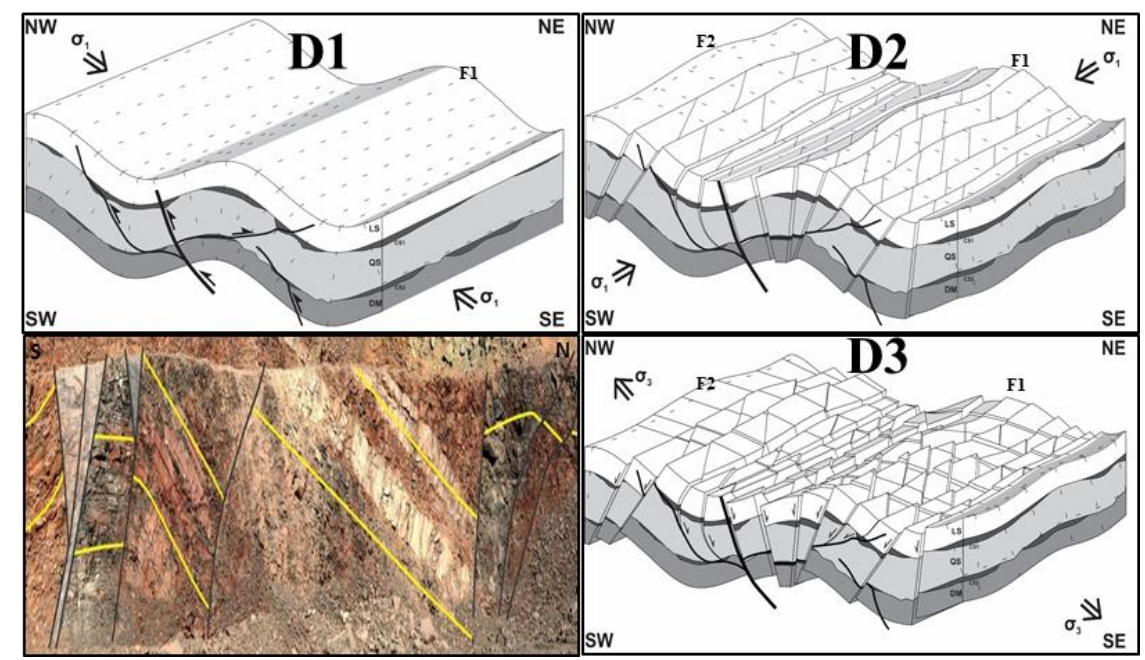

Figure 1: a) An early compression D1 resuting in NE-SW trending folds; b) SW-NE compression D2 resulting in NW trending folds (F2) and intference folding; c) N-S extension resulting in normal faulting wedge shaped blocks; d) combined effect of all deforamtional events. (Creus, et al., 2017)

The steeply dipping bedding planes presents slope stability challenges particularly for the eastern side of the pit where the strike direction of the planes is parallel to the pit slope strike. Single to multiple bench instabilities have over the years been experienced for the eastern side of the pit primarily driven by undercutting of the bedding planes. Consequences of slope failures can range from injury of personnel, damage to equipment, loss of production and possibly force majeure. In this paper we present a solution, determined through extensive data collection and analysis methodologies, aimed at to reducing the afore-mentioned detrimetral consequences. 


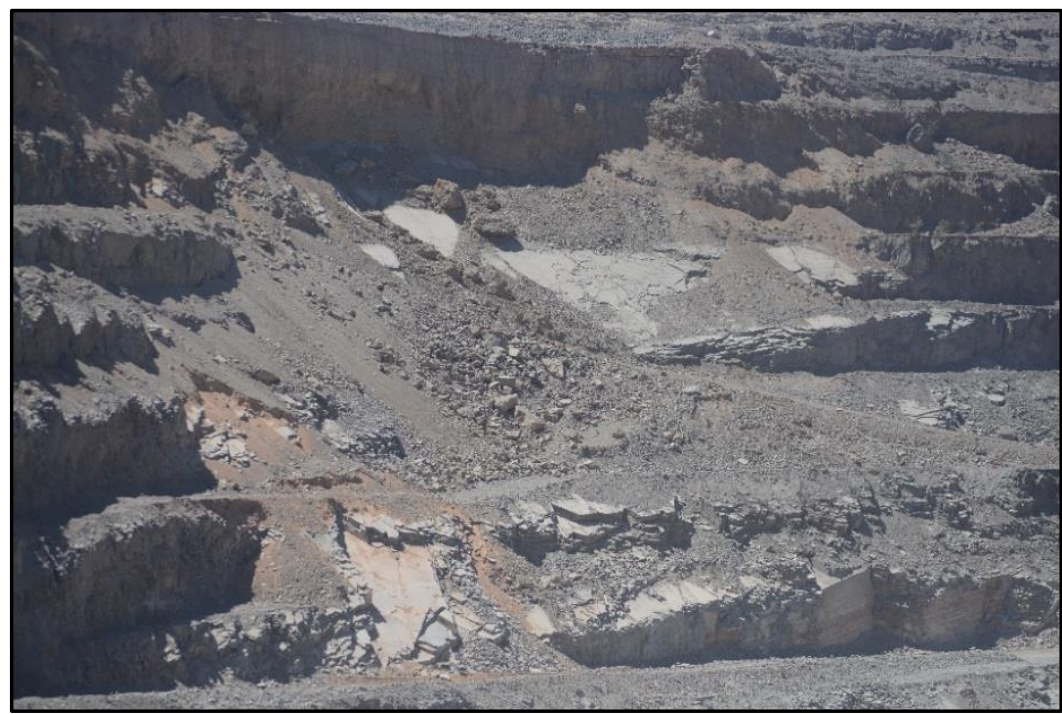

Figure 2: Planar failures on the Jwaneng mine eastern slopes mined with conventional vertical batters

\section{Implementation of the dip slope mining solution}

Planar instability experienced in the eastern slopes is primarily driven by bedding planes dipping steeper than the bedding friction angle. Extensive laboratory testing carried out over time for the shales in Jwaneng mine indicated a friction angle of $37^{\circ}$ (Contreras, 2010). In order to capture for localised variation, data from extensive mapping of exposed faces coupled with downhole geophysics (optical and acoustic televiewer) was used to develop a localised fabric model representing bedding surfaces using the 3D implicit modelling Leapfrog ${ }^{\mathrm{TM}}$ software. An example of a surface waveform has been illustrated in Figure 3 below.

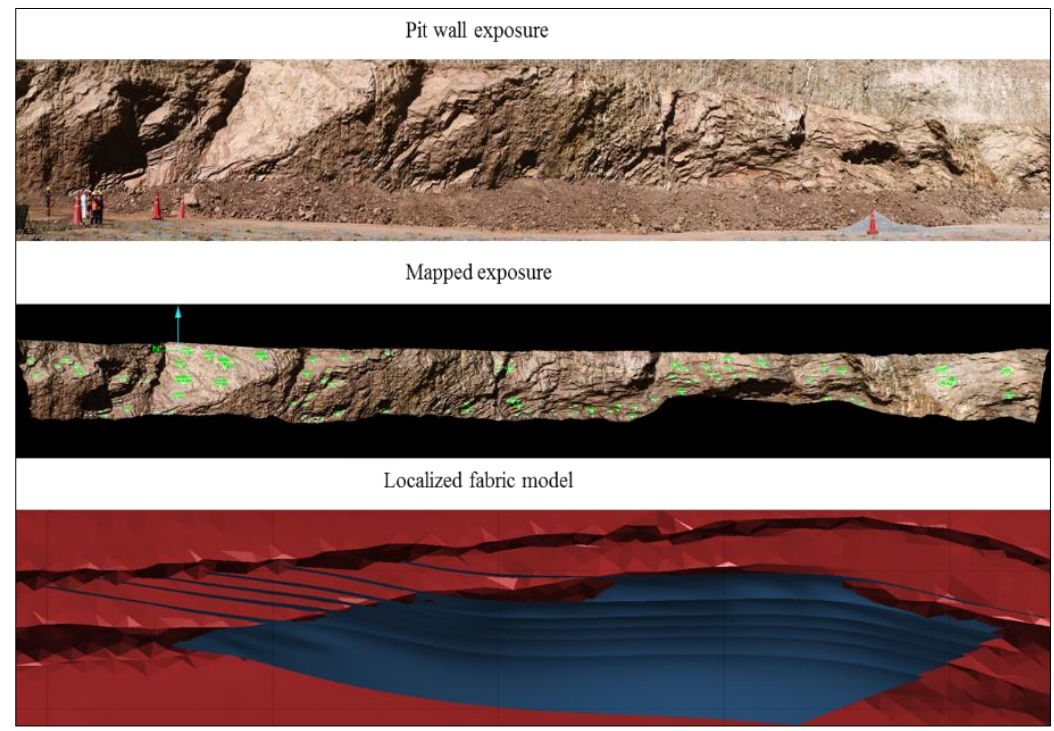

Figure 3: Development of localised fabric based on mapped pit faces

Jwaneng Mine ordinarily adopts vertical batter berm configuration. This conventional configuration leads to instabilities influenced by steep bedding in certain areas. A mining method new to the operation locally referred to as dip slope mining then had to be considered for such areas. The basic principle for this mining method involves mining of benches along the dip of the bedding therefore avoiding undercutting of the planes which is the primary cause of the instability. The criteria for determining bench configuration is based on kinematic feasibility which considers the following and is summarised by Figure 4 below;

- Dip of bedding versus friction angle $\left(37^{\circ}\right)$ 
- Bedding strike versus design slope strike (within approximately $\pm 20^{\circ}$ ) (Wyllie \& and Mah, 2004)

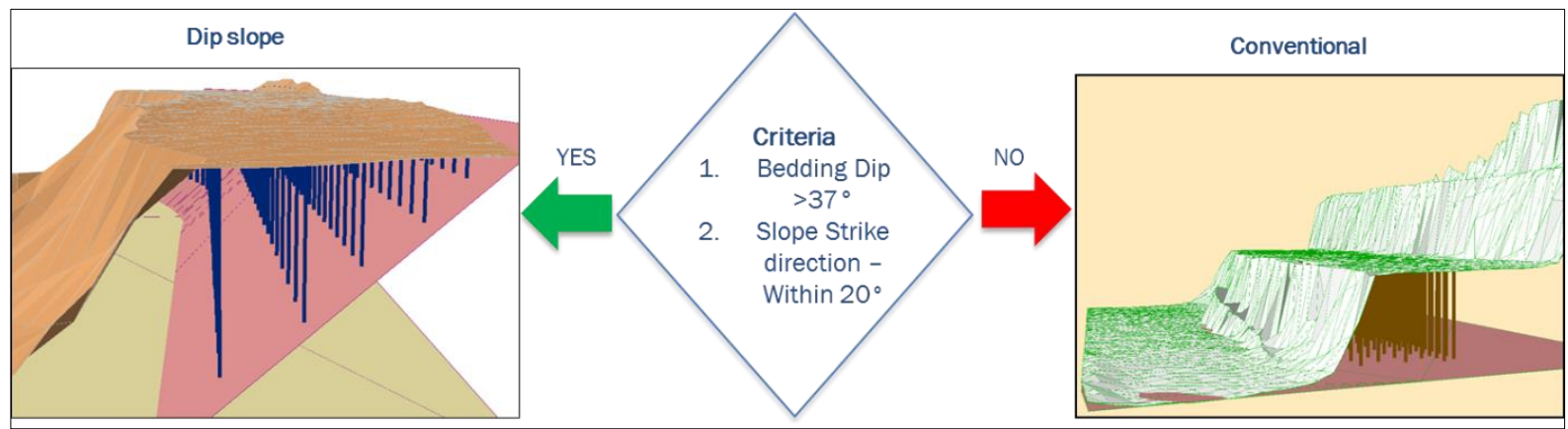

Figure 4: Application of the dip slope mining criteria for bench design configurations

When a mining block has been determined to meet the dip slope mining criteria, a 3D surface inclined at an appropriate angle is created on GEOVIA GEMS ${ }^{\mathrm{TM}}$ software. The inclined surface represents a target plane to which blastholes are designed to as shown by Figure 4 above and eventually mined to. Stringent controls are applied to the drilling and blasting processess to ensure preservation of targeted bedding plane. The implementation of this methodology has led to successful elimination of the intially experienced instabilties due to the undercutting of steep bedding. Figure 5 below shows a comparison of the pit wall conditions before and after implementation of the dip slope mining method.

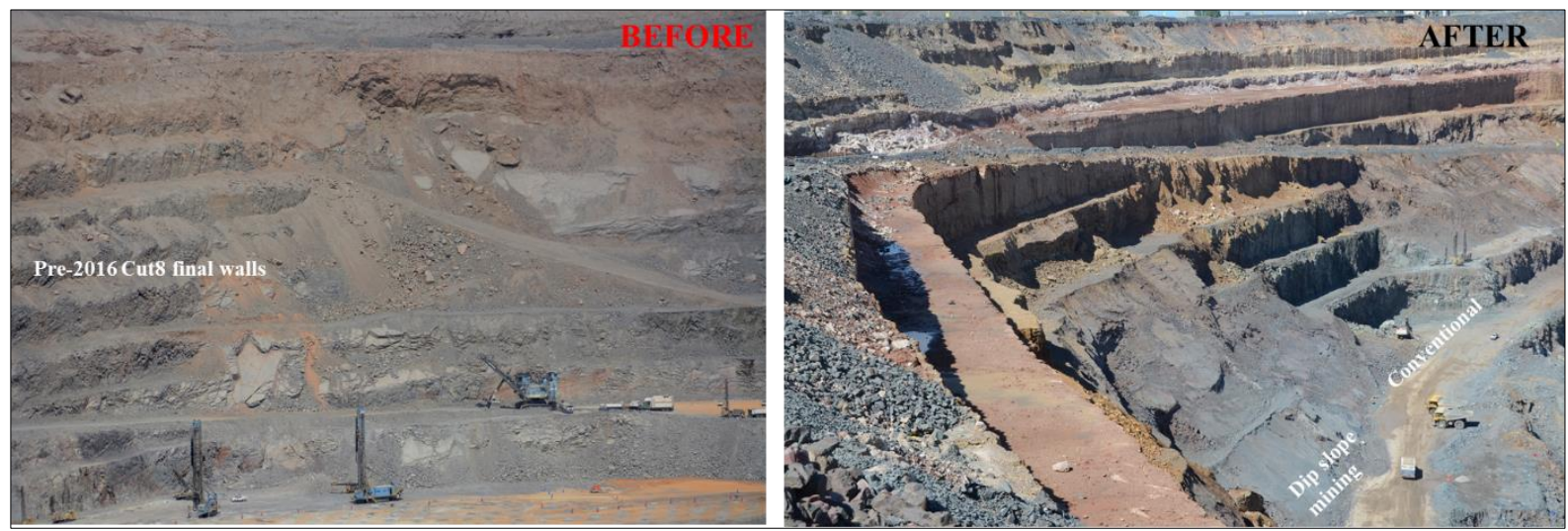

Figure 5: Pit wall conditions before and after implementation of dip slope mining

\section{Conclusions}

The dip slope mining solution proved highly effective in drastically reducing the stability challenges that were experienced in the eastern Cut 8 slopes.

\section{References}

Contreras, L. F., 2010. Jwaneng Mine - Cut 8 Slope Geotechnical Design. SRK Report No 401886, Johannesburg, South Africa: SRK Consulting (South Africa) (Pty) Ltd..

Creus, P. et al., 2017. Structural Analysis and 3D Implicit Modelling of Jwaneng Mine: Insights in to Deformation of the Transvaal Supergroup in SE Botswana. s.l.:s.n.

Wyllie, D. C. \& and Mah, C. W., 2004. Rock Slope Engineering: Civil and Mining. 4th ed. London: Spon Press. 